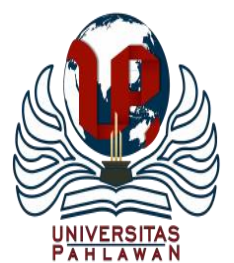

Edukatif : Jurnal Ilmu Pendidikan Volume 3 Nomor 4 Tahun 2021 Halm 2212 - 2219

EDUKATIF: JURNAL ILMU PENDIDIKAN

Research \& Learning in Education

https://edukatif.org/index.php/edukatif/index

\title{
Pelatihan melalui Webinar sebagai Upaya Peningkatan Kinerja dan Kualitas Guru di Masa Pandemi
}

\author{
Muhammad Yudil Khairi \\ Balai Diklat Keagamaan Banjarmasin, Indonesia \\ E-mail : muhammad.yudil12@gmail.com
}

\begin{abstract}
Abstrak
Masa Epidemi virus Covid 19 memaksa perubahan perilaku manusia, terutama interaksi antara manusia untuk mengurangi dampak penyebaran virus ini. Penelitian ini memiliki tujuan untuk mengetahui upaya peningkatan kinerja dan kualitas guru di masa pandemi dengan pelatihan melalui webinar. Penelitian ini menggunakan metode kualitatif. Jenis penelitian ini adalah penelitian kepustakaan yang berarti penelitian yang utamanya menargetkan buku-buku dan literatur lainnya. Didukung kajian penelitian, di masa pandemi ini kinerja dan kualitas guru kurang maksimal apabila dibandingkan dengan saat sebelum pandemi. Di masa pandemi ini, pelatihan perlu dilakukan untuk meningkatkan kinerja dan kualitas guru, meskipun pelatihan hanya dilakukan secara daring. Webinar perlu digalakkan, untuk memberi pelatihan terkait pembelajaran jarak jauh. Dari penelitian ini, dapat disimpulkan bahwa webinar merupakan pilihan pembelajaran yang efektif meningkatkan kinerja dan kualitas guru dalam saat pandemi COVID-19. Selain itu, ini merupakan alternatif model pendampingan yang ramah terhadap larangan pemerintah atas social distancing disaat pandemi COVID-19.
\end{abstract}

Kata Kunci: pelatihan, webinar, kualitas guru.

\section{Abstract}

The Covid-19 epidemic period forced changes in human behavior, especially interactions between humans to reduce the impact of the spread of this virus. This study aims to determine efforts to improve teacher performance and quality during the pandemic by training through webinars. This study uses a qualitative method. This type of research is library research which means research that primarily targets books and other literature. Supported by research studies, during this pandemic the performance and quality of teachers is less than optimal when compared to before the pandemic. During this pandemic, training needs to be carried out to improve teacher performance and quality, even though the training is only conducted online. Webinars need to be encouraged, to provide training related to distance learning. From this study, it can be concluded that webinars are an effective learning option to improve teacher performance and quality during the COVID-19 pandemic. In addition, this is an alternative model of friendly assistance to the government's ban on social distancing during the COVID-19 pandemic.

Keywords: training, webinar, teacher's quality.

Copyright (c) 2021 Muhammad Yudil Khairi

$\triangle$ Corresponding author

Email : muhammad.yudil12@gmail.com

DOI : https://doi.org/10.31004/edukatif.v3i4.1132 


\section{Pelatihan melalui Webinar sebagai Upaya Peningkatan Kinerja dan Kualitas Guru di Masa Pandemi- Muhammad Yudil Khairi}

DOI: https://doi.org/10.31004/edukatif.v3i4.1132

\section{PENDAHULUAN}

Pendidikan di Indonesia merupakan faktor penting yang mendukung keberhasilan pembangunan di Indonesia. Pendidikan sangat diperlukan guna memenuhi kebutuhan sumber daya manusia (SDM) yang memadai di Indonesia. Proses pembelajaran merupakan salah satu bagian dari pendidikan, dimana komponen utama dari proses pembelajaran adalah guru, siswa dan bahan ajar. Hasil studi dari pakar pendidikan (Jalal \& Mustafa, 2001), menyimpulkan bahwa guru merupakan faktor kunci yang paling menentukan dalam keberhasilan pendidikan dinilai dari prestasi belajar siswa (Khadijah, 2018). Guru memilik pengaruh penting yang berperan sebagai pondasi guna menunjang pendidikan anak sebagai pembekalan ilmu di masa depan. Dalam UU Guru dan Dosen No. 14 Tahun 2005, dijelaskan bahwa guru adalah pendidik profesional dengan tugas utama mendidik, mengajar, membimbing, mengarahkan, melatih, menilai, dan mengevaluasi peserta didik pada pendidikan usia dini melalui jalur formal pendidikan dasar dan pendidikan menengah (Tarmini et al., 2020).

Jabatan guru adalah suatu jabatan profesi, dimana harus bekerja secara profesional. Guru profesional adalah guru yang memiliki kompetensi-kompetensi yang dituntut agar mampu melaksanakan tugasnya secara baik dalam melaksanakan fungsi dan tujuan sekolah (Juanita \& Anif, n.d.). Kinerja guru menjadi tolok ukur dari keberhasilan sekolah dalam mencerdaskan dan membentuk karakter siswa sesuai dengan UUD dan Pancasila. Peranan kinerja guru dalam meningkatkan mutu pendidikan sangatlah penting. Hal ini dikarenakan, kinerja guru yang baik akan menunjang proses pembelajaran yang baik pula (Slameto et al., 2017).

Secara lebih terperinci Pemerintah mengusahakan dan menyelenggarakan satu sistem pendidikan nasional, yang dapat meningkatkan keimanan dan ketaqwaan serta akhlak mulia dalam rangka mencerdaskan kehidupan bangsa, yang diatur dengan Undang-Undang (Pasal 31 ayat (3) UUD 1945). Untuk melaksanakan ketentuan tersebut pemerintah telah melakukan berbagai usaha, termasuk menerbitkan Undang-undang Nomor 20 Tahun 2003 tentang Sistem Pendidikan Nasional, Undang-Undang Nomor 14 Tahun 2005 tentang Guru dan Dosen, Peraturan Pemerintah No.74 Tahun 2008 tentang Guru, dan berbagai peraturan lainnya, yang menegaskan peranan strategis guru dan dosen dalam peningkatan mutu pendidikan (Mulyawan, 2012). Karena pentingnya pendidikan dalam tatanan kehidupan, upaya peningkatan kualitas pendidikan perlu dilakukan. Peningkatan kinerja dan kualitas guru merupakan salah satu upaya peningkatan kualitas pendidikan, yang dapat dilakukan melalui pendidikan serta pelatihan (Silvianita \& Yulianto, 2020).

Guru merupakan jabatan profesional yang secara intensif harus dibekali pengalaman melalui pelatihan, karena dengan pelatihan dapat meningkatkan pengetahuan dan keterampilan guru sebagai seorang pegawai dalam melaksanakan tugas-tugas (Somantri et al., 2019). Pelatihan adalah proses dimana orang memperoleh kemampuan untuk membantu mencapai tujuan organisasi. Pelatihan sebagai rangkaian aktivitas yang dirancang untuk meningkatkan keahlian-keahlian, pengetahuan, pengalaman atau perubahan sikap individu (Lailatussaadah, 2015). Kualitas guru sangat bergantung kepada pengalaman dalam pelatihan guru pada sistem pendidikan guru (Mulyawan, 2012).

Era disrupsi adalah era di mana sistem lama diubah menjadi sistem baru karena inovasi teknologi digital. Tidak dapat disangkal bahwa teknologi canggih berperan penting dalam menginspirasi cara hidup, cara mengajar dan cara belajar, yaitu Internet of Things (IoT). Artinya, teknologi telah mempengaruhi setiap aspek kehidupan manusia. Adanya perubahan zaman juga telah membawa perubahan yang tidak dapat dikesampingkan dalam bidang pendidikan, salah satunya adalah konsep dan struktur pembelajaran yang berlaku di Indonesia. Hal ini didukung oleh survei Internet yang dilakukan oleh Asosiasi Penyelenggara Jasa Internet Indonesia (APJII) pada tahun 2016, yang menunjukkan bahwa Indonesia merupakan negara dengan $50,4 \%$ pengguna Internet. Oleh karena itu, pemanfaatan teknologi diharapkan dapat mendorong peningkatan kualitas kemampuan pendidik dalam melaksanakan proses pembelajaran yang melibatkan peserta didik. Selain itu, proses pembelajaran dapat ditingkatkan agar lebih efektif dan efisien, dan karena adanya pandemi menjadi 


\section{Pelatihan melalui Webinar sebagai Upaya Peningkatan Kinerja dan Kualitas Guru di Masa Pandemi- Muhammad Yudil Khairi}

DOI: https://doi.org/10.31004/edukatif.v3i4.1132

solusi yang tepat bagi pemerintah untuk meminta proses pembelajaran jarak jauh. Salah satunya ialah pandemi virus covid-19 (corona), yang merupakan jenis penyakit yang disebabkan oleh virus baru bernama Novel Coronavirus (2019-nCov) yang menyerang saluran pernafasan (Rahmawati et al., 2020).

Pada awal tahun 2020, dunia dikejutkan oleh pandemi virus corona (COVID19) yang berdampak pada sistem pernapasan manusia dan menjadi krisis kesehatan pertama dan terpenting di dunia. Virus yang berasal dari Wuhan, China ini pertama kali masuk ke Indonesia pada 2 Maret 2020. Penyebaran infeksi virus corona ini begitu sederhana dan cepat sehingga jumlah kasus COVID19 di Indonesia juga meningkat sangat pesat. sangat tinggi. Merespon bahaya virus corona dan penyebarannya yang sederhana dan cepat, pemerintah mengeluarkan kebijakan yang melarang masyarakat berkumpul dan beraktivitas di luar ruangan. Pemerintah menetapkan kebijakan yang membatasi jalan-jalan, kegiatan sekolah/universitas diliburkan, bekerja dari rumah bahkan kegiatan ibadah dibatalkan. Hal ini dilakukan untuk mencegah penyebaran virus corona. Beberapa negara yang terpapar penyakit COVID-19 ini juga telah melakukan langkah yang sama, menerapkan kebijakan lockdown atau karantina untuk mengurangi interaksi banyak orang yang dapat terpapar penyebaran virus corona (Inpres et al., 2021).

Ada banyak perubahan dalam pendidikan selama pandemi Covid-19 saat ini. Saat ini, sistem pendidikan online tidak memuaskan banyak orang. Pendidik perlu peduli untuk konsisten dalam memberikan pelayanan pendidikan yang terbaik kepada peserta didiknya. Guru merupakan faktor penting bagi keberhasilan belajar siswa. Oleh karena itu, guru harus memiliki kualitas-kualitas baik yang meningkat dari waktu ke waktu. Di tengah pandemi perubahan sistem pendidikan ini, guru perlu meningkatkan kreativitas pendidikan (Sudarsana \& dkk, 2020).

Jika biasanya para guru bisa dengan leluasa mengikuti pelatihan secara luring atau offline, kali ini guru harus mengikuti pelatihan secara daring. Teknologi yang berkembang di masa kini tidak menutup kemungkinan adanya pelatihan guru secara online. Salah satu pilihan yang kini banyak digunakan oleh sebagian besar masyarakat Indonesia untuk aktivitasnya adalah metode webinar. Istilah "webinar" diusulkan pada tahun 1998 oleh Eric R. Kolb, yang merupakan gabungan dari kata "web" dan "Seminar" yang berarti konferensi internet. Webinar ini dilakukan melalui perangkat yang terkoneksi internet dan menggunakan aplikasi pendukung seperti video conference (zoom, gmeet, dll) untuk digunakan untuk aktivitas jarak jauh. Webinar ini juga digunakan sebagai alternatif metode pelatihan dan pembelajaran generik.

\section{METODE PENELITIAN}

Metodologi penelitian adalah cabang ilmu yang membahas atau mengajukan pertanyaan tentang bagaimana melakukan penelitian (termasuk pencarian laporan, pencatatan, analisis, dan kegiatan redaksional) menurut fakta atau gejala ilmiah. Penelitian ini menggunakan metode kualitatif. Hal ini sebuah pendekatan atau pencarian untuk menyelidiki dan memahami fenomena sentral (Raco, 2018). Penelitian kualitatif (qualitative research) adalah suatu penelitian yang ditujukan untuk mendiskripsikan dan menganalisis fenomena, peristiwa, aktivitas sosial, sikap, kepercayaan persepsi, pemikiran orang secara individual maupun kelompok. Penelitian kualitatif bersifat induktif maksudnya peneliti membiarkan permasalahan-permasalahan muncul dari data atau dibiarkan terbuka untuk interpretasi. Data dihimpun dengan pengamatan yang seksama, mencakup deskripsi dalam konteks yang mendetail disertai catatan-catatan hasil wawancara yang mendalam, serta hasil analisis dokumen dan catatan-catatan (Khadijah, 2018).

Sifat dari penelitian ini adalah penelitian kepustakaan. Penelitian kepustakaan berarti penelitian yang utamanya menargetkan buku-buku dan literatur lainnya (Agnesia \& Hartini, 2020). Penelitian kepustakaan mengumpulkan informasi dan data secara rinci melalui berbagai buku, catatan, jurnal, dan daftar pustaka lainnya, serta hasil pekerjaan sebelumnya yang berkaitan dengan jawaban atas masalah yang akan diteliti dan landasan teori (Yaniawati, 2020). Penelitian ini menghasilkan informasi berupa catatan dan data deskriptif 


\section{Pelatihan melalui Webinar sebagai Upaya Peningkatan Kinerja dan Kualitas Guru di Masa Pandemi-}

Muhammad Yudil Khairi

DOI: https://doi.org/10.31004/edukatif.v3i4.1132

yang terdapat di dalam teks yang diteliti. Adapun sifat dari penelitian ini adalah analisis deskriptif, yakni penguraian secara teratur data yang telah diperoleh, kemudian diberikan pemahaman dan penjelasan agar dapat dipahami dengan baik oleh pembaca (Durahman \& Muhammad Noer, 2019) (Durahman \& Muhammad Noer, 2019).

Desain penelitian yang diambil dalam penulusuran ilmiah ini adalah mix methods studi, cross sectional studi, analisis korelasi, dan kualitatif studi (Sabarua et al., 2020). Intervensi utama yang ditelaah pada penulusuran ilmiah ini adalah pengaruh penggunaan webinar sebagai media pelatihan. Outcome yang di ukur dalam penulusuran ilmiah ini adalah penggunaan webinar sebagai upaya peningkatan kinerja dan kualitas guru di masa pandemi. Penelusuran artikel publikasi pada google, google scholar, dan research gate menggunakan kata kunci yang dipilih yaitu penggunaan webinar dan peningkatan kinerja dan kualitas guru di masa pandemi.

Tabel 1. Sumber Data Base Pencarian Literatur

\begin{tabular}{ll}
\hline Data Base Penelitian & \multicolumn{1}{c}{ Alamat WEB } \\
\hline Google Search & https://www.google.com/ \\
\hline Google Scholar & https://scholar.google.com/ \\
\hline Research Gate & https://www.researchgate.net/ \\
\hline
\end{tabular}

Artikel atau jurnal yang sesuai dengan kriteria inklusi dan eksklusi diambil untuk selanjutnya dianalisis. Penelitian kepustakaan atau kajian literatur ini menggunakan literatur terbitan tahun 2011 - 2021 yang dapat diakses fulltext dalam format pdf dan scholarly (peer reviewed journals). Kriteria jurnal yang direview adalah artikel jurnal penelitian berbahasa Indonesia dengan subyek webinar.

Jurnal yang sesuai dengan kriteria inklusi dan terdapat tema webinar sebagai peningkatan kinerja dan kualitas guru di masa pandemi kemudian dilakukan review. Kriteria jurnal yang terpilih untuk review adalah jurnal yang didalamnya terdapat tema webinar sebagai peningkatan kinerja dan kualitas guru di masa pandemi. Kriteria inklusi penelitian dapat dilihat pada tabel berikut :

Tabel 2. Kriteria Inklusi

\begin{tabular}{ll}
\hline \multicolumn{1}{c}{ Kriteria } & \multicolumn{1}{c}{ Inklusi } \\
\hline Jangka Waktu & Jurnal tahun 2011-2021 \\
\hline Subjek & Webinar \\
\hline Bahasa & Bahasa Indonesia \\
\hline
\end{tabular}

Berdasarkan kriteria inklusi diperoleh hasil sebagai berikut:

Tabel 3. Kriteria Inklusi

\begin{tabular}{llll}
\hline Penelusuran Full Text PDF Tahun 2011-2021 & Google Search & Google Scholar & Research Gate \\
\hline Eligible dengan kriteria inklusi & 40 & 70 & 96 \\
\hline Eligible untuk di analisis & 1 & 2 & 1 \\
\hline Total & \multicolumn{3}{c}{4 Artikel } \\
\hline
\end{tabular}

Penelitian kepustakaan atau kajian literatur ini di sintesis menggunakan metode naratif dengan mengelompokkan data-data hasil ekstraksi yang sejenis sesuai dengan hasil yang diukur untuk menjawab tujuan. Jurnal penelitian yang sesuai dengan kriteria inklusi kemudian dikumpulkan dan dibuat ringkasan 


\section{Pelatihan melalui Webinar sebagai Upaya Peningkatan Kinerja dan Kualitas Guru di Masa Pandemi- Muhammad Yudil Khairi}

DOI: https://doi.org/10.31004/edukatif.v3i4.1132

jurnal meliputi nama peneliti, tahun terbit jurnal, judul penelitian, metode dan ringkasan hasil atau temuan. Ringkasan jurnal penelitian tersebut dimasukan ke dalam tabel sesuai dengan format tersebut di atas. Untuk lebih memperjelas analisis abstrak dan full text jurnal dibaca dan dicermati. Ringkasan jurnal tersebut kemudian dilakukan analisis terhadap isi yang terdapat dalam tujuan penelitian dan hasil/temuan penelitian. Kemudian dengan adanya situasi kondisi saat ini dan didukung dengan adanya data sekunder (dengan mendengarkan radio, berita dan mengali informasi melalui sosial media dan internet) dengan itu peneliti mengambil topik dan judul artikel ini. Dari 4 sumber yang digunakan oleh peneliti semua sumber memuat hal tentang pelatihan melalui webinar sebagai peningkatan kinerja dan kualitas guru di masa pandemi (SUGANDHI, 2016).

\section{HASIL DAN PEMBAHASAN PENELITIAN}

Hasil analisis artikel ini diperoleh melalui cara mengkaji semua jurnal yang diperoleh oleh penulis dengan menggunakan studi literature yang dapat menghasilkan penemuan penelitian baru yang nantinya dapat memberikan masukan atau usaha yang dilakukan terkait judul yang dipilih oleh penulis (Inzani et al., 2021).

Menurut penelitian Muh. Alifian dan Nurul Hidayah (2020) mengenai Analisis Efektivitas Penggunaan Media Webinar dalam Pengembangan Kualitas Guru. Penelitian ini bertujuan untuk menganalisa efektivitas webinar sebagai sebuah media dalam kaitannya terhadap pengembangan kualitas guru. Pendekatan yang digunakan adalah campuran dengan metode kuantitatif dan deskriptif analitis dengan subjek utama penelitian adalah guru di wilayah kota Makassar dan sekitarnya serta pada beberapa wilayah di Indonesia. Data dianalisis secara regresi linier berganda dan diinterpretasikan melalui tabel dan deskripsi, data hasil wawancara direpresentasikan melalui deskripsi dan didukung oleh data sekunder dari penelitian yang relevan. Hasil penelitian ini menunjukkan bahwa pengaruh penguasaan tools serta efektivitas pelaksanaan webinar berpengaruh pada peningkatan kualitas guru. Hingga pada masa pandemi saat ini, pelaksanaan pengembangan guru melalui metode webinar ini cenderung efektif. (Ratulangi \& Lan, n.d.).

Kemudian penelitian yang dilakukan oleh Wini Tarmini, dkk (2020) mengenai Peningkatan Kompetensi Profesional Guru Melalui Webinar Evaluasi Hasil Belajar bagi Guru-Guru MTs. Al-Ma'arif 1 Aimas. Penyusunan instrumen evaluasi hasil belajar dan pelaksanaannya secara daring merupakan salah satu kompetensi profesional yang harus dimiliki oleh guru saat ini. Sebagian besar Guru MTs. Al-Ma'arif 1 Aimas belum terampil dalam memanfaatkan media daring sebagai media penyusunan dan pelaksanaan evaluasi hasil belajar. Kegiatan pelatihan ini bertujuan untuk meningkatkan kompetensi para Guru MTs. Al Ma'arif 1 Aimas, Sorong dalam menyusun instrumen evaluasi hasil belajar secara daring dengan menggunakan media Quizizz. Metode yang digunakan dalam upaya peningkatan kompetensi para guru adalah melalui kegiatan pelatihan. Tahapan yang digunakan dalam pelatihan ini adalah tahap eksplorasi, elaborasi, dan konfirmasi. Tahap eksplorasi diawali dengan pengajuan beberapa pertanyaan melalui Google Form yang berkaitan dengan pemahaman para peserta pelatihan tentang evaluasi dan berbagai media yang dapat digunakan untuk melalukan evaluasi hasil belajar. Tahap elaborasi adalah berupa penjelasan dan pelatihan penyusunan instrumen evaluasi hasil belajarn dengan menggunakan media. Pada tahap konfirmasi para peserta pelatihan diminta untuk menyusun instrumen evaluasi, mengatur waktu pengerjaan, membagikan link dan kode room kepada siswa, dan menganalisis hasil belajar dengan menggunakan penggunaan media Quizizz. Hasil kegiatan menunjukkan bahwa pemahaman dan kompetensi para Guru MTs. Al Ma'arif 1 Aimas Sorong meningkat secara signifikan, yaitu dengan rata-rata awal 25,9\% menjadi $86,6 \%$. Kegiatan pelatihan ini dapat dijadikan salah satu model pelatihan untuk meningkatkan kompetensi profesional para guru.

Selanjutnya penelitian yang dilakukan Samsinar, dkk (2021) mengenai Peningkatan Kualitas Guru di Masa Pandemi Covid-19 dengan Pelatihan Aplikasi Quizizz. Tujuan dari kegiatan adalah meningkatkan kualitas guru selama pandemi Covid-19 dengan memberikan pengetahuan dan pengalaman kepada guru dalam 


\section{Pelatihan melalui Webinar sebagai Upaya Peningkatan Kinerja dan Kualitas Guru di Masa Pandemi- Muhammad Yudil Khairi}

DOI: https://doi.org/10.31004/edukatif.v3i4.1132

membuat dan mengelola kuis secara daring. Berdasarkan hasil pre-test dan post-test disimpulkan bahwa kegiatan pelatihan dapat meningkatkan kemampuan guru dalam mengelola kuis online, serta berdasarkan hasil kuesioner yang diberikan kepada peserta diklat menunjukkan bahwa 52,9\% peserta setuju bahwa materi pelatihan sesuai dengan kebutuhan pekerjaannya saat ini, $76.5 \%$ peserta setuju instruktur menguasai materi dengan baik, 70,6\% peserta setuju bahwa instruktur menjawab pertanyaan peserta dengan jelas dan segera dipahami, dan $88.2 \%$ peserta setuju fasilitas penyelenggaraan workshop online berjalan dengan baik (A, 2016).

Berikutnya penelitian yang dilakukan Sofia S. dan Eko Y. (2020) mengenai Webinar sebagai Kegiatan Peningkatan Kompetensi Widyaiswara pada Masa Pandemi Covid-19. Tujuan penelitian ini adalah untuk mengetahui minat Widyaiswara mengikuti webinar dan persepsi mereka terhadap kegiatan webinar untuk peningkatan kompetensi widyaiswara selama Work From Home (WFH) di masa pandemi COVID-19. Penelitian ini merupakan penelitian kualitatif deskriptif, dengan partisipan berjumlah 62 orang Widyaiswara yang berasal dari 12 Lembaga Diklat Pemerintah di Propinsi Daerah Istimewa Yogyakarta. Data dikumpulkan menggunakan kuisioner dalam bentuk google form yang dibagikan secara daring melalui whatsapp. Data yang telah terkumpul dianalisis secara deskriptif. Hasil penelitian menyatakan adanya minat yang besar widyaiswara untuk mengikuti webinar ditunjukkan dengan 96,77\% Widyaiswara telah mengikuti webinar di masa pandemi COVID-19 dan $90 \%$ diantaranya mengikuti lebih dari 2 kali selama 10 minggu masa WFH. Selain itu 86,67\% merasakan manfaat webinar yang diikuti terhadap peningkatan kompetensinya. Pertimbangan Widyaiswara mengikuti webinar terutama adalah materi yang menarik, mendapatkan sertifikat, dan gratis. Materi yang dianggap menarik dan bermanfaat oleh Widyaiswara terutama adalah materi yang terkait spesialisasi Widyaiswara dan teknologi pembelajaran daring (online) (Silvianita \& Yulianto, 2020).

Didukung kajian penelitian di atas, di masa pandemi ini, kinerja dan kualitas guru kurang maksimal apabila dibandingkan dengan saat sebelum pandemi. Selain karena tanggung jawab guru lebih besar karena harus tetap menjalankan tugasnya dari rumah sebagai seorang pengajar, saat ini guru sudah tidak bisa mengajar secara langsung atau luring, jadi untuk proses pembelajaran hanya dilakukan secara daring lewat social media yaitu Whatsapp group. Kemudian pemberian tugas yang tidak seimbang dengan materi yang diberikan membuat peserta didik dan orang tua merasa tidak puas dengan kinerja mereka sebagai guru, baik peserta didik maupun orang tua mengaharapkan usaha yang lebih terhadap guru dalam melakukan proses pembalajaran. Selain itu banyak peserta didik yang kurang mengerti materi yang diberikan oleh guru di masa pandemic COVID-19 ini, karena proses pembelajaran yang hanya dilakukan secara daring melalui media sosial yaitu Whatsapp group serta kurangnya pemberian materi. Di masa pandemi ini, pelatihan perlu dilakukan untuk meningkatkan kinerja dan kualitas guru, meskipun pelatihan hanya dilakukan secara daring. Webinar perlu digalakkan, untuk memberi pelatihan terkait pembelajaran jarak jauh. Pelatihan ini bertujuan untuk memberikan pemahaman dan keterampilan pendidik dalam memanfaatkan sosial media dan media lainnya dalam melaksanakan pembelajaran daring. Penelitian ini memiliki keterbatasan yaitu pelatihan yang dilakukan secara daring (online) kadang masih terkendala jaringan dan ada beberapa guru yang kurang mampu mengoperasikan media digital.

\section{KESIMPULAN}

Berdasarkan penelitian kepustakaan atau kajian literatur di atas, dapat diambil kesimpulan bahwa pelatihan menggunakan webinar merupakan pilihan yang efektif meningkatkan kinerja dan kualitas guru dalam saat pandemi COVID-19. Dengan webinar, komunikasi interaktif sangat mudah dilakukan dan sumbangsih pengetahuan saling bermunculan. Selain itu, ini merupakan alternatif model pendampingan yang ramah terhadap larangan pemerintah atas social distancing disaat pandemi COVID-19. Namun disisi lain pendampingan ini menjadi fase dalam meningkatkan kompetensi pendidikan yang selama pandemi COVID- 
2218 Pelatihan melalui Webinar sebagai Upaya Peningkatan Kinerja dan Kualitas Guru di Masa PandemiMuhammad Yudil Khairi

DOI: https://doi.org/10.31004/edukatif.v3i4.1132

19 sedikit sulit diwujudkan, hal ini dikarenakan beberapa masalah, seperti masalah akses internet yang tidak stabil menjadi kendala berarti dalam pelaksanaan kegiatan. Hal ini harus menjadi perhatian pihak terkait untuk melakukan optimalisasi akses internet, agar kualitas pendidikan dapat terus maju dan bersaing, meski di masa pandemi Covid-19 yang merebak.

\section{UCAPAN TERIMA KASIH}

Jika perlu berterima kasih kepada pihak tertentu, misalnya sponsor penelitian, nyatakan dengan jelas dan singkat, hindari pernyataan terima kasih yang berbunga-bunga.

\section{DAFTAR PUSTAKA}

A, B. (2016). Pelatihan. -, 9-26.

Agnesia, H., \& Hartini, A. (2020). Pelatihan Pembelajaran Daring Google. 5(2), 148-156.

Durahman, N., \& Muhammad Noer, Z. (2019). Aplikasi Seminar Online (Webinar) Untuk Pembinaan Wirausaha Baru. Jurnal Manajemen Informatika, 6(2), 111-120.

Inpres, S. D., Kecamatan, T., Kabupaten, M., \& Londa, V. Y. (2021). Kinerja Guru Sekolah Dasar Di Masa Pandemi Covid-19 Studi Di Sd Inpres Tateli Kecamatan Mandolang Kabupaten Minahasa. Jurnal Administrasi Publik, 7(99), 1-11.

Inzani, D. A., Ar, A., Halisa, N., Fauzi, L. A., Rahmat, M., Syukur, M., Sofyan, M., \& Najamuddin, F. (2021). Webinar Pelatihan Media Pembelajaran Di Masa Pandemi Covid-19. Journal Lepa-Lepa Open, 1(1), 143-151. Https://Ojs.Unm.Ac.Id/Jllo/Article/View/16867

Juanita, S., \& Anif, M. (N.D.). Peningkatan Kualitas Guru Di Masa Pandemi Covid-19 Dengan Pelatihan Aplikasi Quizizz. 57-64.

Khadijah, S. (2018). Efektivitas Pelatihan Kompetensi Dalam Peningkatan Kinerja Guru Di Smpn 1 Batang Gangsal. Jurnal Mitra Manajemen, 1(2), 151-163. Https://Doi.Org/10.52160/Ejmm.V1i2.20

Lailatussaadah, L. (2015). Upaya Peningkatan Kinerja Guru. Intelektualita, 3(1), 243106.

Mulyawan, B. (2012). Issn 1412 - 8683 45. Jurnal Undiksha, 11, 45-65. Https://Ejournal.Undiksha.Ac.Id/Index.Php/Mkfis/Article/View/453

Raco, J. (2018). Metode Penelitian Kualitatif: Jenis, Karakteristik Dan Keunggulannya. Https://Doi.Org/10.31219/Osf.Io/Mfzuj

Rahmawati, E., Abidin, Z., Purwanti, S. N., Khasanah, A., \& Luhur, D. (2020). Webinar Peran Teknologi Dalam Pembelajaran Di Masa. Proceeding Of The 12th University Research Colloquium 2020: Pengabdian Kepadar Masyarakat, 27-32. Http://Repository.Urecol.Org/Index.Php/Proceeding/Article/View/1099

Ratulangi, S., \& Lan, S. (N.D.). Analisis Efektivitas Penggunaan Media Webinar Dalam Pengembangan Kualitas Guru Analysis Of The Effectiveness Of Using The Webinar Medium In Teacher Development. 217-222.

Sabarua, J. O., Patalatu, J. S., \& Besare, S. D. (2020). Pelatihan Pembelajaran Daringbagi Guru-Guru Sekolah Dasar Guna Meningkatkan Literasi Digital Di Masa Pandemi Covid-19. Jurnal Abdimas Ilmiah Citra Bakti, 1(2), 147-155. Https://Doi.Org/10.38048/Jailcb.V1i2.122

Silvianita, S., \& Yulianto, E. (2020). Webinar Sebagai Kegiatan Peningkatan Kompetensi Widyaiswara Pada Masa Pandemi Covid-19. Paedagoria: Jurnal Kajian, Penelitian, Dan Pengembangan Kependidikan, 11(2), 113-119. 
2219 Pelatihan melalui Webinar sebagai Upaya Peningkatan Kinerja dan Kualitas Guru di Masa PandemiMuhammad Yudil Khairi

DOI: https://doi.org/10.31004/edukatif.v3i4.1132

Slameto, Sulasmono, B. S., \& Wardani, K. W. (2017). Peningkatan Kinerja Guru Melalui Pelatihan Beserta Faktor Penentunya. Jurnal Pendidikan Ilmu Sosial, 27(2), 38-47. Http://Journals.Ums.Ac.Id/Index.Php/Jpis/Article/View/5718

Somantri, O., Abidin, T., Wijayanto, S., Wibowo, D. S., \& Dairoh, D. (2019). Peningkatan Kompetensi Guru Melalui Pelatihan Keterampilan Pembuatan E-Presentation. Jurnal Solma, 8(2), 219. Https://Doi.Org/10.29405/Solma.V8i2.3245

Sudarsana, I. K., \& Dkk. (2020). Covid-19: Perspektif Pendidikan (Issue October).

Sugandhi, D. F. P. (2016). Pemanfaatan Hasil Belajar Pada Pelatihan Keterampilan Mekanik Otomotif: Studi Kasus Pada Lulusan Lembaga Pendidikan Keterampilan Pelita Massa. 1984, 7-41. Http://Repository.Upi.Edu/Id/Eprint/20501

Tarmini, W., Safi'i, I., Witdianti, Y., \& Larassaty, S. (2020). Peningkatan Kompetensi Profesional Guru Melalui Webinar Evaluasi Hasil Belajar Bagi Guru-Guru Mts Al-Ma'arif 1 Aimas. Transformasi: Jurnal Pengabdian Masyarakat, 16(1), 53-62. Https://Doi.Org/10.20414/Transformasi.V16i1.2049

Yaniawati, P. (2020). Penelitian Studi Kepustakaan. Penelitian Kepustakaan (Liberary Research), April, 15. 